\title{
Pengembangan Sistem Informasi Pada Local E-Govervenance Untuk Peningkatan Kinerja Pelayanan Warga
}

\author{
Hariadi Yutanto*1, Romi Ilham², Kautsar Riza Salma ${ }^{3}$, Yusuf Effendi ${ }^{4}$ \\ STIE Perbanas, Surabaya \\ Naskah Diterima : 12 Oktober 2019; Diterima Publikasi : 24 November 2019
}

DOI : 10.21456/vol9iss2pp220-227

\begin{abstract}
The problems that often arise in the neighborhood of Neighborhood Unit (RT) and Rukun Warga (RW) are the distribution of information on citizen activities, administration, transparent financial management, and management of citizen databases as an effort to improve services and information facilities for residents. The purpose of this study is to support the government in implementing e-Government-based government systems, by developing Good Local Governance. The specific target of innovation to be achieved is the development of innovation in the form of a web-based Citizen Information System (SiWarga) application at the RT / RW level. The method used in this study uses the System Development Life Cycle (SDLC Waterfall) method, starting from the first is analyzing the needs by conducting a survey and the feasibility of developing the system, second is to make a detailed list according to system requirements specifications, third is to design the system by creating workflow designs and programming design, the fourth is the development of information systems with coding, the fifth is system testing, the sixth is the implementation and maintenance of the system
\end{abstract}

Keywords : SiWarga; Information Systems; Local E-Government; Performance of Citizen Services

\begin{abstract}
Abstrak
Permasalahan yang kerap muncul di lingkungan Rukun Warga (RW) dan Rukun Warga (RW) adalah distribusi informasi tentang aktivitas warga, administrasi, pengelolaan keuangan yang transparan, dan pengelolaan basis data warga sebagai upaya meningkatkan layanan dan fasilitas informasi untuk penghuni. Tujuan dari penelitian ini adalah untuk mendukung pemerintah dalam menerapkan sistem pemerintahan berbasis e-Government, dengan mengembangkan Good Local Governance. Target spesifik inovasi yang ingin dicapai adalah pengembangan inovasi dalam bentuk aplikasi Sistem Informasi Warga (SiWarga) berbasis web di tingkat RT / RW. Metode yang digunakan dalam penelitian ini menggunakan metode System Development Life Cycle (SDLC Waterfall), mulai dari yang pertama adalah menganalisis kebutuhan dengan melakukan survei dan kelayakan pengembangan sistem, kedua adalah membuat daftar terperinci sesuai dengan spesifikasi kebutuhan sistem , ketiga adalah merancang sistem dengan menciptakan desain alur kerja dan desain pemrograman, yang keempat adalah pengembangan sistem informasi dengan pengkodean, yang kelima adalah pengujian sistem, yang keenam adalah implementasi dan pemeliharaan sistem
\end{abstract}

Kata kunci: SiWarga; Sistem Informasi; Local E-Govervenance; Kinerja Pelayanan Warga

\section{Pendahuluan}

Dalam mewujudkan Good Governance, pemerintah saat ini menerapkan sistem e-government di Indonesia. E-government adalah sistem pemerintah yang berbasis pada teknologi komunikasi. Pada prinsipnya, inovasi e-government ini adalah untuk meningkatkan kualitas proses layanan dari lembaga pemerintah ke publik melalui layanan online (Chen \& Perry, 2003). Saat ini ada banyak lembaga pemerintah di negara ini yang sudah memiliki sistem berbasis elektronik yang cukup canggih, mulai dari Sistem Manajemen Keuangan Daerah (SKPD), e-HR, eMonitoring, e-Education, e-Permit, e -Office, e-

*) Penulis korespondensi: antok@perbanas.ac.id
Health, e-Dishub, Pusat Media untuk Sistem Peringatan Bencana. Dengan melihat kompleksitas yang dimiliki, tentu saja pemerintah kota sangat peduli dalam mengembangkan e-governance, tetapi harus diingat bahwa dalam sistem pemerintahan terdapat elemen-elemen yang membangun pemerintahan, mulai dari sistem pemerintah pusat hingga sistem terendah. pemerintah (RT) dan Rukun Warga (RW). Tata pemerintahan yang baik dan turunannya, seperti Pemerintahan Daerah yang Baik, adalah salah satu paradigma terbaru dalam wacana implementasi tata kelola. Penerapan Good Local Governance di daerah harus diselaraskan dengan strategi dalam memaksimalkan fungsi pemerintahan, terutama di 
bidang pemenuhan kebutuhan publik yang transparan (Yandra, 2016).

Permasalahan yang kerap muncul di lingkungan Rukun Warga (RW) dan Rukun Warga (RW) adalah distribusi informasi tentang aktivitas warga, administrasi, pengelolaan keuangan yang transparan, dan pengelolaan basis data warga sebagai upaya meningkatkan layanan dan fasilitas informasi untuk penghuni. Sistem informasi di masyarakat memiliki peran yang sangat penting dalam membangun sistem informasi kependudukan sebagai upaya pemenuhan hak setiap warga negara. Sejalan dengan ini, pengumpulan data kependudukan perlu diatur sebaik mungkin, sehingga dapat memberikan manfaat dalam meningkatkan tata kelola dan pembangunan, di mana pengelolaan data kependudukan menjadi tanggung jawab Pemerintah Kabupaten / Kota di tingkat Kabupaten / Kota. Rukun Tetangga (RT) sebagai ujung tombak masyarakat memainkan peran penting dalam hal ini.

Griya Pesona Asri (GPA) adalah perumahan yang berlokasi di Kecamatan Rungkut dan kelurahan Medokan Ayu, Rukun Warga (RW) 10 Surabaya. Sebanyak 5 Rukun Tetangga (RT) dengan populasi sekitar 400 Kepala Keluarga. Perumahan yang telah merencanakan berbasis IT telah membuat sistem keamanan di lingkungan perumahan dengan mengembangkan sistem keamanan CCTV di setiap RT di setiap titik rentan yang dapat dipantau secara online oleh penduduk selain itu perumahan ini juga telah mengimplementasikan jaringan wifi hotspot dilingkungan perumahaan GPA pada setiap titik berbasis captive portal dimana setiap warga dapat mengakses layanan wifi menggunakan akun setiap blok Rumah (H.Yutanto, 2018). Kendala saat ini adalah manajemen administrasi seperti mengelola surat, membayar iuran dan database warga masih bersifat offline meskipun mereka telah menggunakan aplikasi kantor Microsoft Office (Word \& Excel). Beberapa Kendala yang dirasakan oleh warga adalah 1. Kesulitan dalam pengurusan administrasi RT karena waktu. 2. Pembyaran setiap bulan warga harus menyetor pembayaran tunai ke RT bendahara 3 . Permohonan layanan yang masih terbentur oleh waktu

Tujuan khusus dari penelitian ini adalah untuk mengembangkan SiWarga di lingkungan Grup Lingkungan yang dapat meningkatkan layanan dan fasilitas informasi bagi warga, selain itu penduduk juga dapat mengontrol laporan keuangan warga secara transparan. Berbeda dengan kondisi saat ini yang masih menggunakan proses manual dalam melakukan proses pembukuan dan menyampaikan informasi kepada warga dengan mendatangi rumah-rumah warga satu per satu. Mempertimbangkan program pemerintah dalam mewujudkan Pemerintahan yang Baik di Indonesia, pentingnya penelitian ini mengembangkan sebauh sistem untuk meningkatkan layanan dan kenyamanan warga.

\section{Kerangka Teori}

\subsection{Mainframe Paltform}

Perkembangan sistem informasi RT/RW sudah beraneka ragam dan telah diimplementasikan pada beberapa RT/RW di Indonesia. Secara garis besar dari pengembangan sistem aplikasi yang ada dapat dibagi menjadi tiga aplikasi. Pertama, aplikasi desktop based adalah aplikasi ini dapat berjalan sendiri atau independen tanpa menggunakan browser atau koneksi internet di suatu computer otonom, dengan operating system atau platform tertentu (Akay et al., 2014; Lin \& Lin et al., 2018). Kedua, aplikasi web based adalah aplikasi yang dapat berjalan dengan menggunakan basis teknologi web atau browser. Aplikasi ini dapat diakses dimana saja asalkan ada koneksi internet yang mendukung tanpa perlu melakukan penginstalan dimasing-masing komputer seperti aplikasi desktop, cukup dengan membuka browser dan menuju tempat server aplikasi tersebut dipasang (Bressolles et al., 2014; Tikno, 2017). Ketiga, aplikasi mobile based adalah aplikasi yang sekilas hampir sama dengan web based namun ada empat perbedaan yang membuatnya berbeda jika dilihat dari fitur, interaksi user, location awareness dan push notification. Sementara dilihat dari koneksi aplikasi terdapat dua jenis koneksi, yaitu koneksi secara online, yang artinya kita sedang terhubung dengan internet atau dunia maya, baik itu terhubung lewat akun media social, email dan berbagai jenis akun lain nya yang kita pakai atau gunakan lewat internet. Sedangkan offline adalah suatu istilah untuk sebutan kita tidak terhubung dengan internet, lebih tepat nya tidak terkoneksi. Sehubungan dengan aplikasi yang akan dikembangkan, maka aplikasi ini merupakan aplikasi web based dengan koneksi online.

\subsection{E-Government}

E-government adalah tentang penyampaian informasi pemerintah dan penyelenggaraan pelayanan secara online melalui internet atau alat digital lainnya (Chen \& Perry, 2003). E-Government dapat diaplikasikan pada legislatif, yudikatif, atau administrasi publik, untuk meningkatkan efisiensi internal, menyampaikan pelayanan publik, atau proses kepemerintahan yang demokratis. EGoverment di Indonesia mulai dilirik sejak tahun 2001 yaitu sejak munculnya Instruksi Presiden No. 6 Tahun 2001 tgl. 24 April 2001 tentang Telematika yang menyatakan bahwa aparat pemerintah harus menggunakan teknologi telematika untuk mendukung good governance dan mempercepat proses demokrasi. Namun dalam perjalanannya inisiatif pemerintah pusat ini tidak mendapat dukungan serta respon dari segenap pemangku kepentingan pemerintah yaitu ditandai dengan pemanfaatan teknologi informasi yang belum maksimal, dikarenakan pelaksanaan EGovernment di Indonesia sebagian besar barulah pada tahap publikasi situs oleh pemerintah atau baru pada 
tahap pemberian informasi. Penelitian dilakukan oleh Anita \& Widodo, (2014) berupa sistem informasi RT/RW sebagai media komunikasi warga berbasis web yang hanya sebatas penyampaian informasi. Penelitian dilakukan juga oleh (Lukman, 2015) mengenai manajemen aplikasi RT/RW Net yang hasilnya merupakan Network Operating Center (NOC) yang berguna untuk mengkoneksikan seluruh warga yang ada di lingkungan RT/RW dengan berbagai perangkat yang dibutuhkan.

\subsection{Basis Data}

Database adalah suatu kumpulan atau susunan data operasional lengkap dari suatu organisasi yang diorganisir atau dikelola dan disimpan secara terintegritasi dengan menggunakan metode tertentu menggunakan komputer sehingga mampu menyediakan informasi yang optimal yang diperlukan pemakainya. Sedangkan sistem basis data adalah suatu sistem penyusunan dan mengelola record-record menggunakan komputer untuk menyimpan atau merekam serta memelihara data operasional lengkap sebuah organisasi atau perusahaan sehingga mampu menyediakan informasi yang optimal yang diperlukan pemakai untuk proses pengambilan keputusan.

Menurut Marlinda (2004) pengertian Basis Data adalah: "Kumpulan file yang mempunyai kaitan antara satu file dengan file lain sehingga membentuk satu bangunan data untuk menginformasikan suatu perusahaan instansi, dalam batasan tertentu". Kesimpulan di atas adalah basis data merupakan suatu kumpulan dari data yang saling berhubungan satu dengan yang lainnya, tersimpan dalam sebuah komputer dan digunakan perangkat lunak untuk memanipulasinya.

\subsection{Bahasa Pemrograman PHP}

PHP merupakan salah satu bahasa scripting yang terpasang pada HTML. Sebagian besar sintaks mirip dengan bahasa C, Java dan Perl, ditambah beberapa fungsi PHP yang spesifik. Tujuan utama bahasa ini adalah untuk memungkinkan perancang web menulis halaman web dinamik dengan cepat. PHP ditulis dan diperkenalkan pertama kali sekitar tahun 1994 oleh Rasmus Lerdorf melalui situsnya untuk mengetahui siapa saja yang telah mengakses ringkasan online-nya.

PHP merupakan bahasa berbentuk skrip yang ditempatkan dalam server dan diproses di server PHP merupakan bahasa berbentuk skrip yang ditempatkan dalam server dan diproses di server. Hasilnya akan dikirimkan ke client, tempat pemakai menggunakan browser. PHP dikenal sebagai sebuah bahasa scripting, yang menyatu dengan tag-tag HTML, dieksekusi di server, dan digunakan untuk membuat halaman web yang dinamis seperti halnya Active Server Pages (ASP) atau Java Server Pages (JSP). PHP merupakan sebuah software open source. Secara khusus, PHP dirancang untuk membentuk web dinamis. Artinya, ia dapat membentuk suatu tampilan berdasarkan permintaan terkini. Pada prinsipnya, PHP mempunyai fungsi yang sama dengan skrip-skrip seperti ASP (Active Serever Page), Cold Fusion, maupun Perl.

\section{Metodologi}

\subsection{Lokasi Penelitian}

Lokasi penelitian dilakukan di Perumahan Griya Pesona Asri (GPA), RT 4, Rukun Warga (RW) 10 Kecamatan Medokan Ayu Rungkut, SurabayaIndonesia.

\subsection{Object Penelitian}

Object penelitian yang dilakukan peneliti adalah perancangan sistem informasi Warga yang memuat tentang informasi data warga dan keuangan KAS RT di Perumahan Griya Pesona Asri

\subsection{Metode Pengumpulan Data}

Jenis data dalam penelitian ini adalah data primer menggunakan penelitian lapangan, yaitu penelitian yang dilakukan dengan mendekati objek penelitian. Pengumpulan data yang dilakukan yaitu :

a. Observasi (Observasi); Dalam mengumpulkan data dan informasi untuk melengkapi hasil penelitian ini, penulis melihat langsung pada objek penelitian.

b. Wawancara; Pengumpulan data melalui wawancara, penulis melakukan tanya jawab secara lisan dengan RT, RW, Kelurahan dan pihak terkait.

\subsection{Metode Pengembangan Sistem}

Pengembangkan Sistem Informasi Warga (SiWarga), menggunakan metode System Development Life Cycle (SDLC) dengan Waterfall (Kute \& Thorat, 2014). Waterfall Model adalah metode pengembangan perangkat lunak berurutan. Selain itu model ini adalah model yang paling banyak digunakan oleh pengembang perangkat lunak. Tahapan yang dilakukan dalam pengembangan Sistem Informasi Warga ini sebagai berikut :

1. menganalisis kebutuhan dengan melakukan survei dan kelayakan pengembangan sistem,

2. membuat daftar terperinci sesuai dengan spesifikasi kebutuhan sistem ,

3. Merancang sistem dengan menciptakan desain alur kerja dan desain pemrograman,

4. Pengembangan sistem informasi dengan pengkodean,

5. Pengujian sistem,

6. implementasi dan pemeliharaan sistem

\subsection{Perancangan Sistem}

1. Context Diagram

Pada gambar 1 merupakan ruang lingkup pengembangan sistem yang dijabarkan kedalam sebuah konteks diagram. 


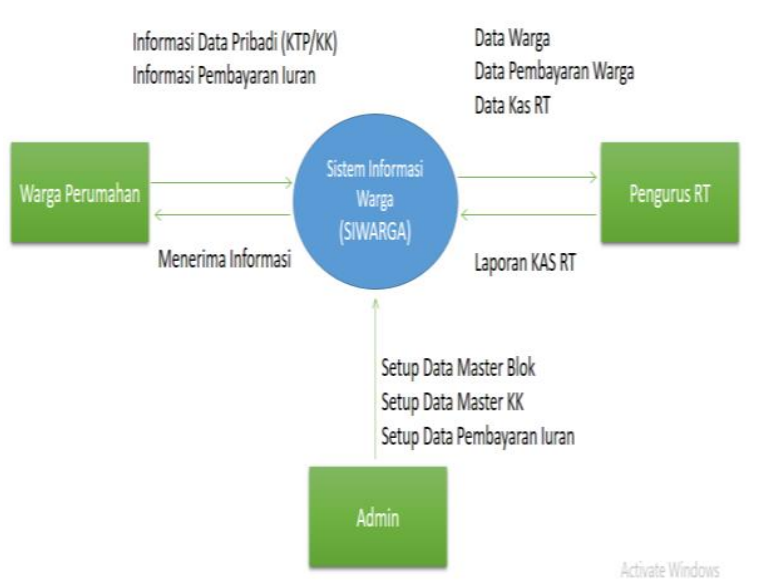

Gambar 1. Konteks Diagram

Konteks diagram tersebut yang berisi tentang hubungan antar aktivitas sistem informasi Warga sebagai berikut

1. Warga yang dapat memanfaatkan sistem informasi Siwarga untuk menambah data, membayar iuran dan menerima informasi.

2. Pengurus RT dapat memonitoring dan menambah data warga, data memonitoring kas RT serta pembayaran warga.

3. Admin melakukan konfigurasi, pembuatan user dan update berita RT

\section{Diagram Overview (DFD Level 0)}

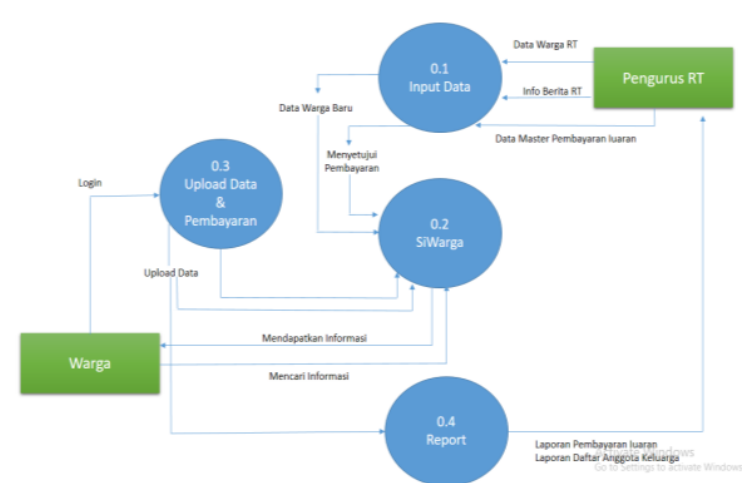

Gambar 2. DFD Level 0

Pada gambar 2 yaitu DFD Level 0 menjelaskan tentang penjabaran aktivitas pada konteks diagram seperti

1. Pengurus RT/Admin melakukan setup awal untuk siwarga antara lain setup master kompleks (maste blok, master blok rumah dan KK. Dilanjutkan dengan setup master Kewajiban Warga (Master kewajiban, Kewajiban detail dan master pengeluaran. Berikutnya adalah entry data Web yaitu Data Warga, Data pembayaran (monitoring dan menyetujui pembayaran iuran, Update Web dan Galery.

2. Setiap warga memiliki laman portal login, yang diberikan oleh Pengurus RT/admin, warga dapat melakukan update data warga, melakukan upload bukti pembayaran melalui transfer dan setiap warga dapat memberikan hak suara pada saat evoting pemilihan Ketua RT.

3. Pengurus RT dan Warga dapat melakukan monitoring aktivitas data warga termasuk pembayaran iuran warga

\section{Hasil dan Pembahasan}

\subsection{Tampilan Login Pengurus RT / Admin}

Pada Gambar 3 merupakan tampilan beranda atau bisa disebut halaman dashboard dari sistem. Setelah melakukan login kedalam sistem, sistem akan menampilkan halaman dashboard. Halaman dashboard menampilkan grafik jumlah penduduk, jumlah penduduk berdasarkan jenis kelamin, dan data pembayaran Iuran Warga.



Gambar 3. Dashboard Ketua RT / Admin

\subsection{Setup Data Master Komplek}

Proses Selanjutnya yang dialakukan oleh admin adalah melakukan halaman data master blok rumah dapat dilihat pada gambar 4, pada perumahan Griya Pesona Asri terdapat lima blok yaitu blok J, K, L dan M.

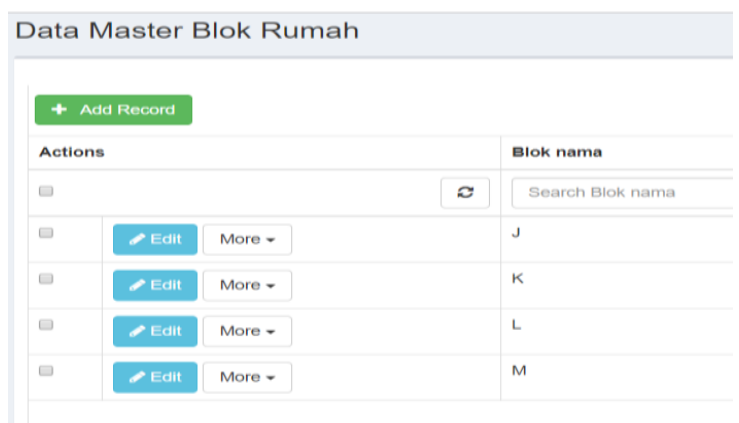

Gambar 4. Data Master Blok

Dilanjutkan dengan melakukan input data warga sesuai dengan master blok rumah. Total jumlah rumah adalah 140 Rumah dan total penghuni adalah $121 \mathrm{KK}$ 


\subsection{Setup Master Kewajiban}

Pada gambar 5 merupakan data master untuk melakukan setup pembayaran warga ada 2 tipe pembayaran yaitu Iuran Kampung dan Iuran Sampah, sedangkan besaran dapat diinput sesuai dengan kondisi pembayaran RT.

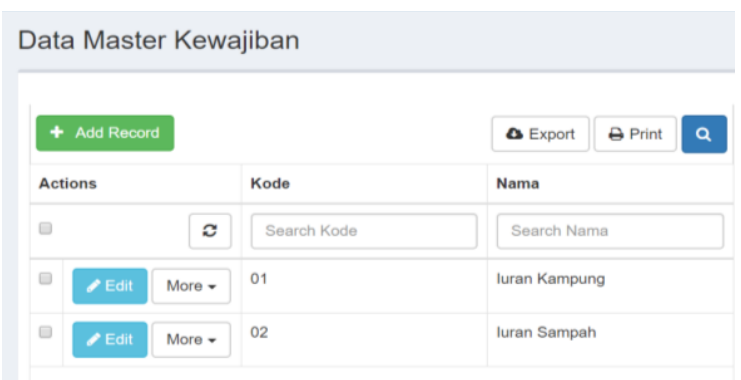

Gambar 5. Master Kewajiban

Proses selanjutnya adalah melakukan proses generate tagihan kewajiban yang akan di didistribusikan kepada masing-masing warga. Proses generate pun dilakukan sesuai dengan kebutuhan.

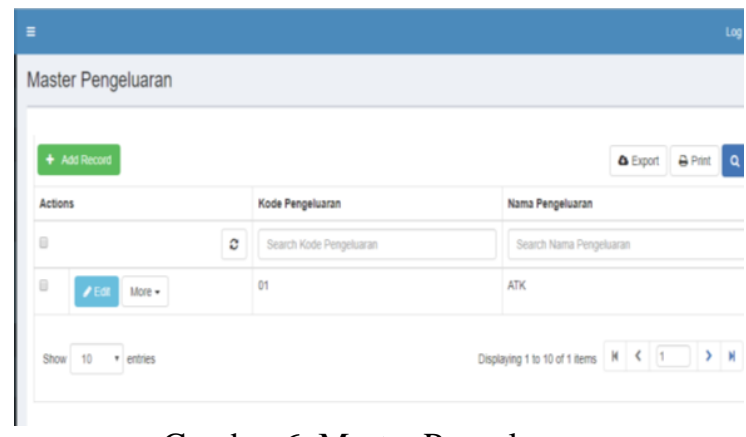

Gambar 6. Master Pengeluaran

Pada gambar 6 merupakan master setup pengeluaran keuangan RT yang di proses oleh bendhara RT dapat dilihat bahwa distirbusi tagihan di proses pada periode 1 tahun.

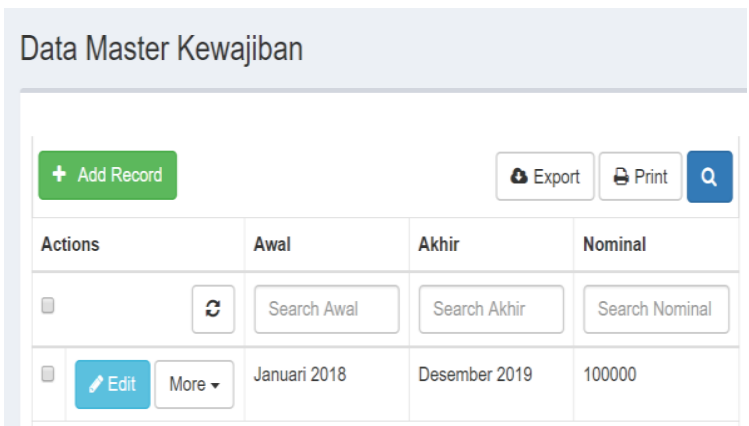

Gambar 7. Master Periode Kewajiban

Pada gambar 7 merupakan master pengeluaran Kas RT, yaitu dapat dilakukan input oleh perngurus setiap aktivitas pengeluaran kebutuhan kampung seperti pengeluaran pembayaran petugas sampah, satpam dan pembangunan kampung.

\subsection{Setup Master Pemilihan Ketua RT (e-vote)}

Pada fitur menu master pemilihan adalah ada 3 menu yaitu setup pemilihan, setup kandidat pemilihan (Gambar 8) dan setup periode pemilihan (Gambar 10). Calon RT dapat di setup pada setup kandidat RT dan untuk periode pemilihan dapat di setup pada periode waktu pemilihan. Setelah dilakukan setup pemilihan setiap warga yang telah mengakses portal siwarga secara otomatis dapat memberikan hak suara secara online. Hasilnya pun dapat tersaji secara realtime.

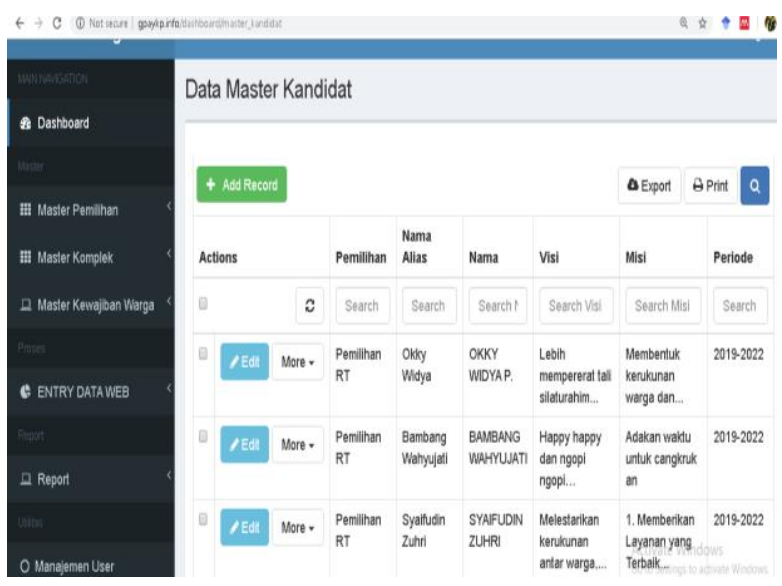

Gambar 8. Master Kandidat RT

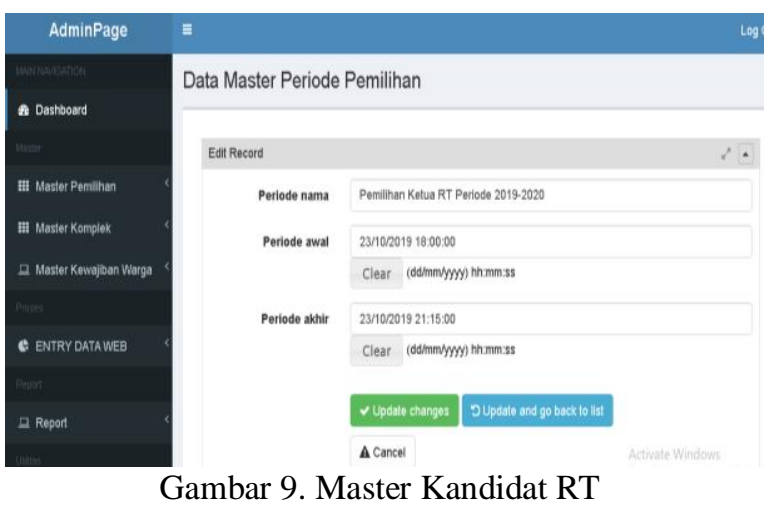

\subsection{Halaman Report Pengurus RT/Admin}

Pada laman report yang tersaji adalah report jumlah warga, report pembayaran untuk melakukan approve pembayaran yang dilakukan oleh warga setelah melakukan pembayaran dan upload bukti bayar (Gambar 10). Pengurus RT bagian bendhara akan mendapatkan notifikasi di system dan melakukan verifikasi bukti transfer dengan ebanking. Setelah iuran masuk pengurus melakukan approve penerimaan pembayaran iuran warga. Sedangkan pada portal laman website Siwarga setiap warga dapat melakukan monitoring report pembayaran iuran per bulan dan monitoring data warga. Tahapan selanjutnya yang dilakukan oleh Pengurus RT / admin adalah melalukan approve / menyetujui pembayaran warga yang di upload melalui portal laman masingmasing warga. 


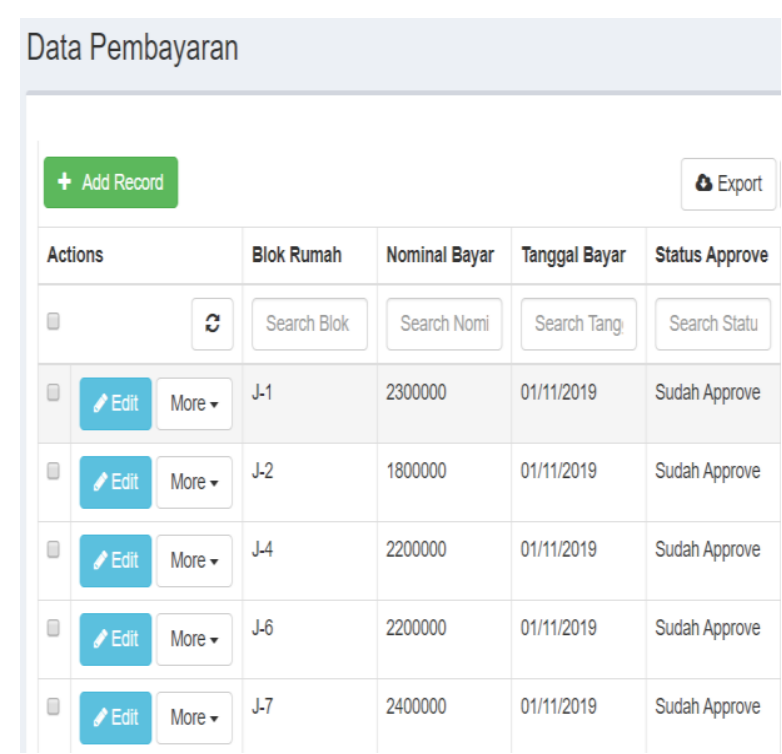

Gambar 10. Data Pembayaran Warga

\subsection{Halaman Portal Warga}

Halaman portal warga ada beberapa fitur yang dapat dimanfaatkan oleh setiap warga antara lain fitur untuk upload data KTP dan KK, kemudian setiap warga dapat melakukan upload bukti transfer dan monitoring iuran. Pada gambar 11 merupakan tampilan layout portal login warga

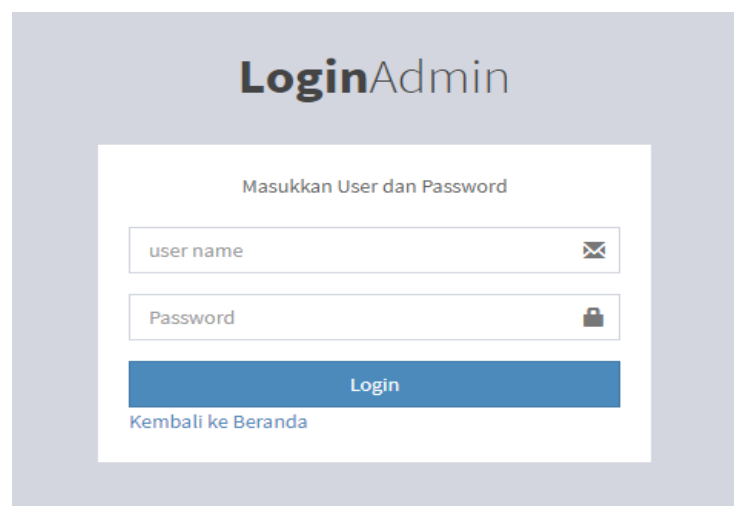

Gambar 11. Login Portal Siwarga

Setelah berhasil login setiap warga dapat menambahkan anggota keluarga dapat dilihat pada gambar 12. Sedangkan pada gambar 13 merupakan form yang digunakan oleh warga ketika melakukan pembayaran iuaran melalui transfer bank dan melakukan upload bukti transfer, setelah itu akan muncul pada portal admin (pengurus) yang akan melakukan proses pengecekan pembayaran warga. Jika bukti transfer dan dana iuran sudah masuk secara otomatis akan di approve

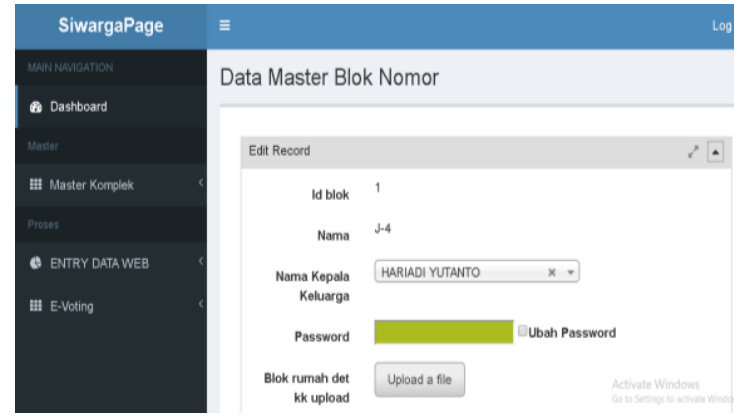

Gambar 12. Data warga di Portal Siwarga

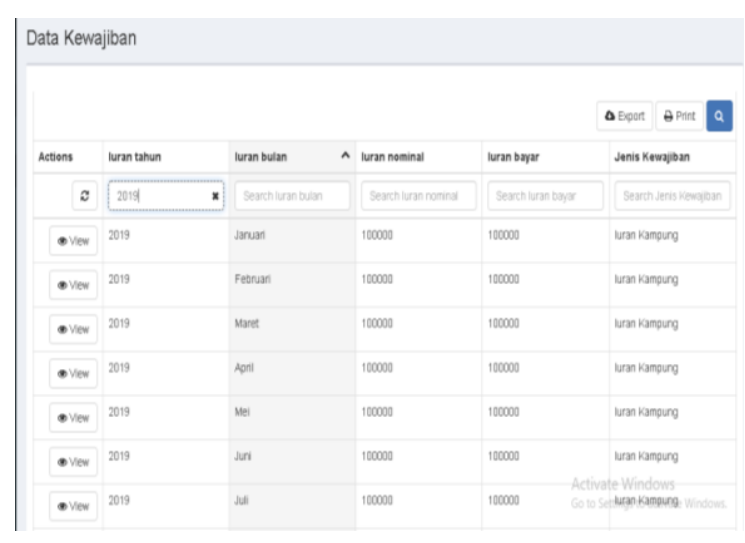

Gambar 13. Data Kewajiban Pembayaran

Pada gambar 14 merupakan menu hasil generate tagihan iuran yang muncul pada portal siwarga setiap warga pun dapat memonitoring pembayaran Iuran setiap bulan yang telah dibayarkan dan di approve oleh pengurus RT.

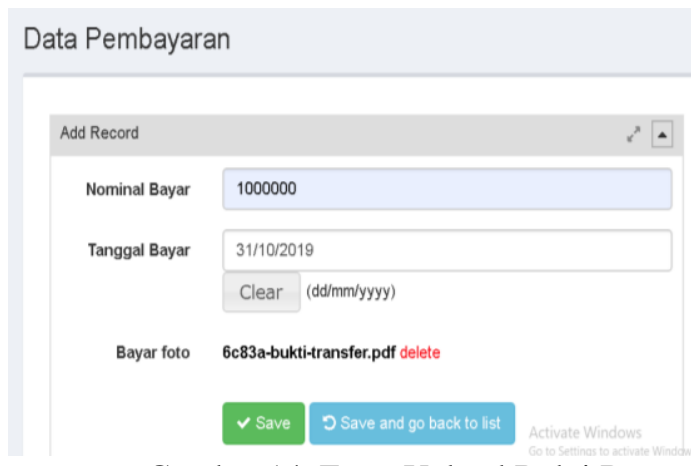

Gambar 14. Form Upload Bukti Bayar

Teknis pembayaran yang dilakukan oleh warga adalah

1. Warga melakukan transfer ke rekening RT

2. Warga meng capture bukti transfer

3. Warga login melalui portal siwarga kemudian melakukan upload bukti bayar dan menunggu pembayaran di approve / disetujui

4. Monitoring pembayaran Iuran tagihan hasil pembayaran. 
Form pada gambar 14 merupakan upload data pembayaran serta monitoring pembayaran yang dilakukan oleh setiap warga.

Salah satu fitur tambahan di portal siwarga adalah penambahan fitur $e$-voting untuk pemilihan Ketua RT. Setiap warga dapat memeberikan hak pilih pemilihan Ketua RT. Teknis pemungutan suara proses pun secara teknis hanya dapat dilakukan ketika Pengurus RT / Admin memberikan jadwal untuk pemilihan RT dan proses pemilihan hanya dapat dilakukan satu kali untuk setiap rumah warga / KK.

Hasil perolehan suara pun dapat dilihat secara real count pada masing-masing portal aplikasi Siwarga.

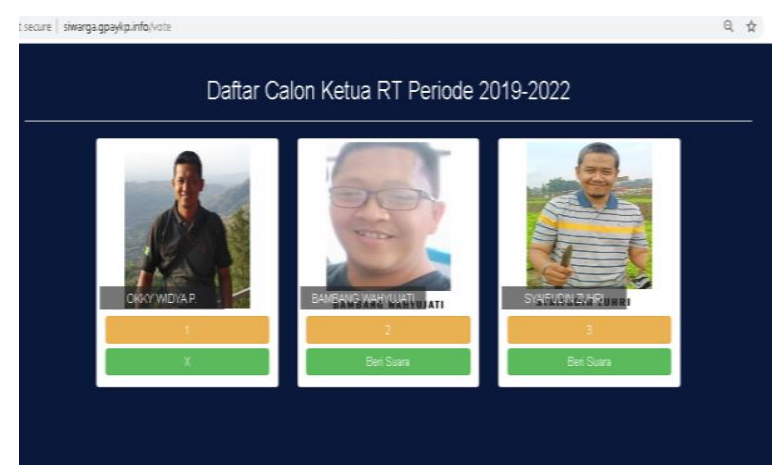

Gambar 15. Master Calon RT

Gambar 16 merupakan gambar para calon ketua RT yang tampil di laman siwarga sehingga masingmasing warga dapat memilih pada waktu pemilihan ketua RT. Informasi pemilihan para calon dan jadwal disosilisasikan oleh Pengurus RT dan KPU RT melalui media Web RT di http://gpaykp.info

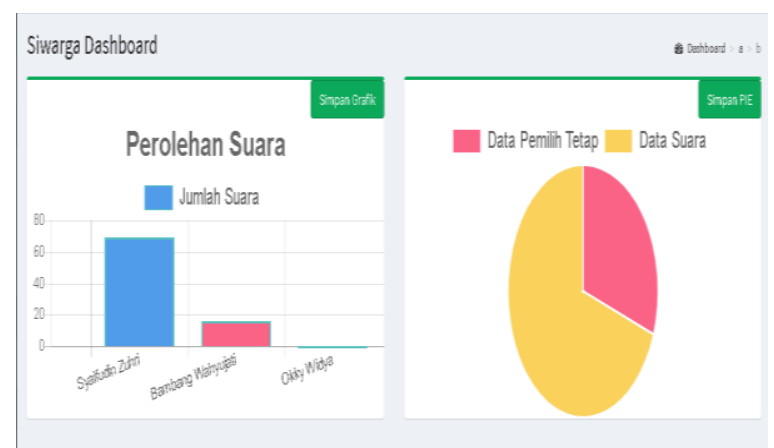

Gambar 16. Real Count

Sedangkan pada gambar 17 merupakan gambar tampilan hasil pemilihan RT yang dapat dipantau secara online oleh setiap warga. Total terdapat $120 \mathrm{KK}$ yang terdaftar menjadi daftar pemilih tetap. Total $70 \%$ warga memilih melalui aplikasi Siwarga.

\section{Kesimpulan}

Berdasarkan hasil dari penelitian pengembangan System Informasi Warga (SiWarga) yang telah diimplementasikan di Perum GPA RT 04 RW 10, maka peneliti mengambil kesimpulan yaitu penelitian ini dapat membantu operasional layanan informasi kepada masyarakat. Selain itu kemudahan akses dalam monitoring database warga, administrasi dan keuangan iuran secara transparansi iuran dapat diakses oleh pengurus dan setiap warga melalui portal http://siwarga.gpaykp.info, selain itu warga sangat antusias menggunakan aplikasi Siwarga, hal ini dapat dibuktikan pada saat pemanfaatan e-voting pemilihan RT yang proses sebelumnya menggunakan cara manual (fisik) tahun 2016 hanya 20\% warga yang memilih ini meningkat menjadi $70 \%$ pemilih pada saat menggunakan aplikasi siwarga dari total 120 Keluarga. Penelitian selanjutnya yaitu melakukan survey tentang kepuasan \& pemanfaatan penggunaan aplikasi Siwarga dengan menggunakan metode TAM. mengembangkan integrasi dengan sistem pembayaran seperti OVO atau Gopay selain itu peneliti berencana mengintegrasikan peralatan IOT (remote system Penerangan Jalan Umum dan cctv) dengan aplikasi Siwarga. Saat ini

\section{Ucapan Terima Kasih}

Ucapan terima kasih kepada segenap sivitas akademika, khususnya tim ICT STIE Perbanas Surabaya dan Pengurus serta warga RT4 RW 10 Perumahan Griya Pesona Asri Surabaya yang telah mendukung mulai dari diskusi perencanaan, tahapan implementasi Sistem Informasi Warga (Siwarga) menuju kampung digital sebagai wujud inovasi dan pioner di kelurahan Medokan Ayu melalui laman http://gpaykp.info dan http://siwarga.gpaykp.info sehingga portal web dapat diimplentasikan dan sebagai media informasi pengelolaan database, evoting \& keuangan kas RT.

\section{Daftar Pustaka}

Akay, M.E., Poputra, A.T., Kalalo, M., 2014. Analisis aspek keperilakuan terhadap penerapan sistem akuntansi persediaan pada PT. Surya Wenang Indah Manado, 688. Jurnal EMBA, 4(1), 688-697.

Anita \& Widodo, S., 2014. Sistem informasi RT/RW sebagai media komunikasi warga berbasis web. SMATIKA Jurnal, 4 (November), 20-26.

Bressolles, G., Durrieu, F. \& Senecal, S., 2014. A consumer typology based on e-service quality and e-satisfaction. Journal of Retailing and Consumer Services, 21(6), 889-896. https://doi.org/10.1016/j.jretconser.2014.07.004

Chen, Y.C., \& Perry, J., 2003. Outsourcing for EGovernment. Public Performance \& Management Review, 26(4), 404-421. https://doi.org/10.1177/1530957603252590

Kute \& Thorat, 2014. A Review on Various Software Development Life Cycle (SDLC) Models. International Journal of Research in Computer and Communication Technology 
Kute, S.S. \& Thorat, S.D., 2014. A Review on various Software Development Life Cycle (SDLC) Models. IJRCCT, 3(7), 776-781. Retrieved from http://ijrcct.org/index.php/ojs/article/view/784

Lin, S. H. \& Lin, T.M.Y., 2018. Demand for online platforms for medical word-of-mouth. Journal of International Medical Research, (43), 030006051875789.

https://doi.org/10.1177/0300060518757899

Lukman, M.S., 2015. Manajemen Aplikasi RT/RW Net di Paku Haji. Universitas Mercu Buana Menteng.
Marlinda, L., 2004. Sistem Basis Data. Yogyakarta: Andi Offset.

Tikno., 2017. Measuring performance of facebook advertising based on media used: A case study on online shops in Indonesia. Procedia Computer Science,

111 ,

105-112. https://doi.org/10.1016/j.procs.2017.06.016

Yandra, A., 2016. E-goverment dengan memanfaatkan teknologi informasi. Jurnal Kajian Politik dan Masalah Pembangunan, 12(01), 17691780.

Yutanto, H., 2018. Penerapan model promosi berbasis web captive portal hotspot dengan manajemen terpusat. JSINBIS (Jurnal Sistem Informasi Bisnis), vol. 8, no. 1, pp. 49-56, Apr. 2018. https://doi.org/10.21456/vol8iss1pp49-56 